\title{
Eucalyptus recurva (Myrtaceae), a new species from the Southern Tablelands of New South Wales
}

\author{
M.D. Crisp
}

\begin{abstract}
Crisp, M.D. (Australian National Botanic Gardens, G.P.O. Box 1777, Canberra, Australia 2601) 1988. Eucalyptus recurva (Myrtaceae), a new species from the Southern Tablelands of New South Wales. Telopea 3(2): 223-230. - A remarkable mallee eucalypt discovered recently near Braidwood is described and named. It is placed in sect. Maidenaria, and its affinity to other species discussed. Conservation status of the new species, which is known only from a single small stand, is assessed.
\end{abstract}

In August 1985, Ms. R. Jean, a landholder from near Braidwood, New South Wales, brought to the Australian National Botanic Gardens a fragment of a very odd mallee eucalypt that she had found in her local area. With its small, crowded, recurved leaves, the specimen presented such an unusual aspect that at first glance, it looked as though it belonged to the Rutaceae. A closer examination of the specimen, followed by a visit to the population in the field, revealed that Ms. Jean had in fact discovered a very distinctive new species of Eucalyptus. Seed was collected but only with some difficulty was it propagated and a seedling established. Together with adult parts, the seedling provided evidence as to the relationships of the new mallee to other eucalypts.

This paper describes E. recurva, suggests its most likely affinity, and discusses aspects of its horticulture, genetic variability and conservation status.

\section{Eucalyptus recurva Crisp, sp. nov.}

Frutex 'mallee' ad $1.7 \mathrm{~m}$ altus, lignotuber formans, cortice laevi, partibus omnibus praeter illas magis ligneas glandibus oleosis abundantibus prominentibus; cotyledonibus leviter bilobis; caule plantulae anguste quadrialato; foliis juvenilibus intermediisque decussatis, sessilibus, apicibus recurvatis, obovatis, 4-21 x $1.5-7 \mathrm{~mm}$, hebetato-virentibus, nervo mediano conspicuo flavo, venis obscuris; foliis adultis ut videtur non evolutis; foliis in planta matura ad initium tempus anni crescendi folia intermedia simulantibus, postea magis patentibus, angusto-ellipticis, usque ad $28 \times 7 \mathrm{~mm}$, acuminatis, venis visibilibus; internodiis brevibus $(2-12 \mathrm{~mm})$; inflorescentiis in axillis singulis, 3-floris, pedunculis 4-5.5 mm longis; alabastris subsessilibus, late obovoideis, inter hypanthium operculumque leviter constrictis, usque ad $6 \times 5 \mathrm{~mm}$; hypanthio hemisphaerico; operculo hemisphaerico, breviori angustiorique; operculo exteriori scarioso, in 4-5 lobos persistentos deltoideos mature findenti; filamentis staminum in alabastro inflexis; antheris versatilibus; ovario 3-4 loculari; stylo clavato brevi; fructu subsessili, depresso-hemisphaerico, 2.5-3.5 x 4.5-6 mm, disco angusto, valvis vix inclusis; semine irregulariter depressoellipsoideo, badio, hilo ventrali. 
Holotype: New South Wales: NE of Braidwood, M.D. Crisp 7698 \& I.R. Telford, 11.11.1985 (CBG). ISOTYPES: CBG, HO, K, MEL, NSW.

Mallee to $1.7 \mathrm{~m}$ tall; bark smooth, decorticating in ribbons, green when freshly exposed, weathering through orange-brown to grey, lacking oil glands; forming a lignotuber; stems slender, crooked; canopy rather open; whole plant except the woodier parts abundantly dotted with large (c. $0.25 \mathrm{~mm}$ diam.) oil glands. Cotyledons slightly bilobed. Seeding-leaves (to 11th node) decussate, sessile, spreading, obovate or narrow-obovate, rounded and recurved at apex, tapered to base, decurrent, 4-21 x 1.5-7 mm, dull green; stem quadrangular, narrowly winged, abundantly glandular. Coppice (intermediate) leaves decussate, sessile, ascending, obovate, rounded to acute and recurved at apex, minutely crenulate at margins, shortly tapered to base, 6-13 x 4-6 mm, abundantly glandular, dull green; mid-rib conspicuous, yellow; veins obscure; stem obscurely quadrangular, with short $(2-6 \mathrm{~mm})$ internodes. Adult leaves apparently not developed; leaves on mature plant resembling coppice leaves early in season's growth, becoming more spreading, narrow-elliptic, up to $28 \mathrm{x}$ $7 \mathrm{~mm}$, acuminate, tapered to both ends, with main lateral veins more or less visible above; internodes increasing to $12 \mathrm{~mm}$. Unit inflorescences one per axil; peduncles compressed, becoming terete, $4-5.5 \mathrm{~mm}$ long, c. $1.5 \mathrm{~mm}$ broad. Buds 3 per unit inflorescence, broad-ovoid, slightly constricted between hypanthium and operculum, up to $6 \times 5 \mathrm{~mm}$, pitted with dense oil glands; middle bud shortly $(1 \mathrm{~mm})$ pedicellate; lateral buds sessile; hypanthium hemispherical, to $3 \times 5 \mathrm{~mm}$; operculum hemispherical, shorter and narrower than hypanthium, to $2 \mathrm{x}$ $3.5 \mathrm{~mm}$; outer operculum scarious, splitting to base into 4-5 persistent, irregular, deltoid lobes soon after bracts have fallen. Stamens: filaments mostly inflexed in bud, white; anthers versatile, very broad-ovate to square in outline, opening in vertical slits, $0.5 \mathrm{~mm}$ long. Ovary with 3 or 4 locules; ovules in 4 longitudinal rows on lower part of placenta; style clavate, short (c. $2.5 \mathrm{~mm}$ ); stigma blunt with a lobed surface and short papillae. Fruit subsessile, depressedhemispherical, slightly constricted at orifice, 2.5-3.5 x 4.5-6 mm; hypanthium pitted with oil glands; disc narrow $(0.75 \mathrm{~mm}), \pm$ level; valves just below rim, 3 or 4 . Seed irregularly ellipsoid, depressed, $0.8-1.3 \mathrm{~mm}$ long, $0.7-1.0 \mathrm{~mm}$ broad, $0.3-0.4 \mathrm{~mm}$ thick, shallowly reticulate, semi-lustrous, dark red-brown; hilum ventral. Figs 1, 2.

FLowering PERIOD: January.

ETYMOLOGY: The specific epithet is Latin, meaning 'curved backwards', and refers to the leaf apices. Conspicuously recurved leaf apices are very rare in eucalypts, and are much more developed in E. recurva than in any of its close relatives.

DISTRIBUTION: known only from a single stand near Braidwood on the Southern Tablelands of New South Wales.

Specimens Examined: New South Wales: Southern Tablelands: NE of Braidwood, $G$. Baker \& R. Jean, 8.1985 (CBG 8502702); M.D. Crisp 7699 \& I.R. Telford, 11.11.1985 (CBG, MEL, NSW); M.D. Crisp 7725 \& I.R. Telford, 14.2.1986 (CBG, MELU, MO); R. Jean, 31.1.1986 (CBG 8600351).

HABITAT: The type locality is a low ridge in undulating tableland country. There, E. recurva is growing in pale sandy clay, which supports a low heathland dominated by Allocasuarina nana (Sieber ex Sprengel) L. Johnson and Hakea dactyloides (Gaertn.) Cav.

CONSERVATION Status: Endangered, coded 2E (criteria from Leigh et al. 
1984). Eucalyptus recurva is known only from a single stand, which apparently consists of five individuals. It appears to be the rarest species in the genus; $E$. carnabyi Blakely \& Steedman is known from one individual in Western Australia, but is generally supposed to be a hybrid (Pryor \& Johnson 1971, Chippendale 1973).

Even in the absence of external threats, the single known population of $E$. recurva must be endangered by its extremely narrow genetic base. Estimates of the number of individuals necessary to maintain a viable population vary widely (Fisher 1978, Ellyard 1987 and references cited in these), but by any standard, five may be too few. In fact, there is evidence that E. recurva is suffering the effects of inbreeding. Very few seeds are set (about one per capsule), and a good proportion of those appear to lack embryos. Attempts by M.A. Clements to germinate seed at the Australian National Botanic Gardens have met limited success. After stratification, seven out of ten seeds germinated but only one established a seedling. The survivor struggled to produce three pairs of leaves over several months, and then died. Subsequently, another batch of seed treated similarly produced a single seedling which grew slowly, reaching $10 \mathrm{~cm}$ in height after four months (Fig. 2F). The lack of seedling vigour suggests that a postzygotic lethality system may be operating in this taxon.

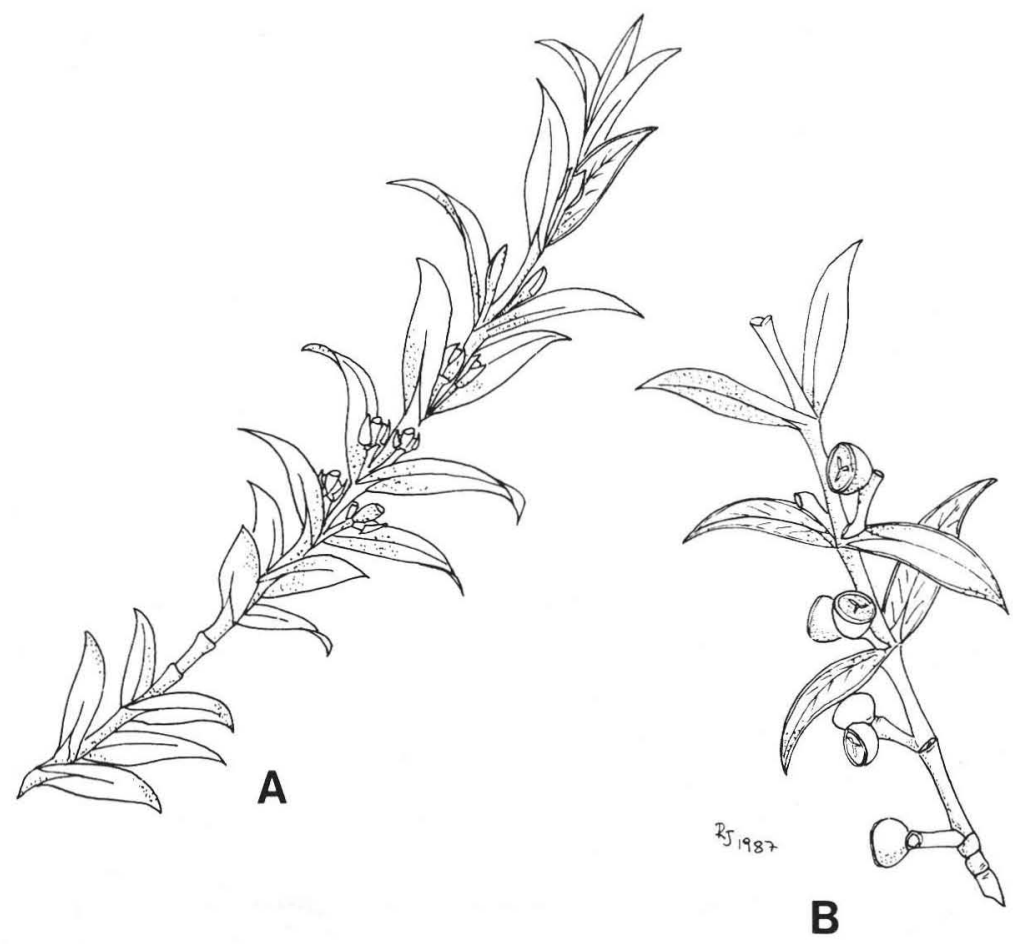

Fig. 1. Eucalyptus recurva Crisp. A, branchlet with developing buds (x 0.9). B, branchlet with fruit (x 0.9). (Both from life; R. Jean del.) 

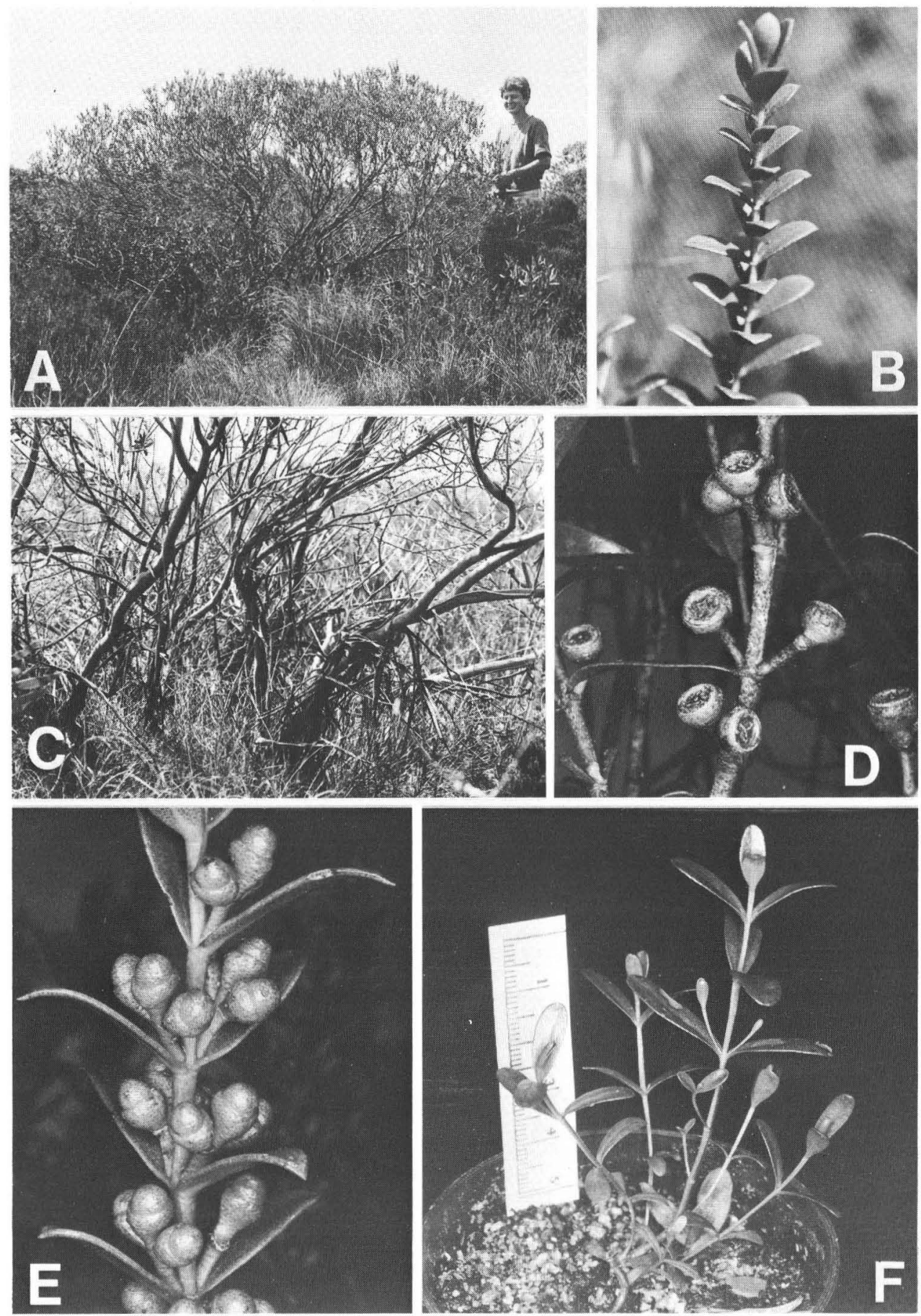

Fig. 2. Eucalyptus recurva Crisp. A, habit. B, coppice shoot from lignotuber, showing early intermediate leaves (x 1). C, stems. D, fruit (x 1.3). E, buds and late intermediate leaves (x 1.3). F, seedling (scale in $\mathrm{cm}$ ). (All from life.) 
It is quite likely that the five plants in the natural stand comprise a clone. They form a circular patch no more than $7.5 \mathrm{~m}$ in diameter, which could have originated by peripheral growth and central decay of a single parental lignotuber. Leaf samples were taken from each plant in January 1987 and subjected to an allozyme analysis by G. Moran (CSIRO Division of Forest Research, Canberra). All ten enzymes analysed were uniform and homozygous in all five plants. While such a result is consistent with the plants belonging to a clone, it is not conclusive.

Eucalyptus recurva occurs on private land that at present is largely undisturbed. However, the lignotuber of one individual has been disturbed by vehicles. As far as is known, the present landholder intends to preserve the population of $E$. recurva but, as long as the site is unreserved, it must have a degree of insecurity.

There has been only a partial search for additional stands of E. recurva in the surrounding district. The present site is similar to other heathlands around Braidwood that are dominated by Allocasuarina nana. A good proportion of these localities has been explored by botanists already, and it seems unlikely that extensive populations of $E$. recurva remain undiscovered.

AFFINITY: Eucalyptus recurva belongs in Pryor and Johnson's (1971) informal sect. Maidenaria but may be taxonomically rather isolated there. According to Boland et al. (1984), sect. Maidenaria is diagnosed by reniform or bilobed cotyledons and more or less sessile juvenile leaves. In both characters, $E$. recurva is typical of this section. Similarly shaped cotyledons do occur in closely related sections, such as Exsertaria and Adnataria. Sessile juvenile leaves also are found, although rarely, in these and other sections of $E$. subgen. Symphyomyrtus. Thus, these characters may be synapomorphies at a higher taxonomic level than that of sect. Maidenaria, and should not be relied upon exclusively in diagnosing the group.

Carr and Carr (1969) suggested that the presence of oil glands in the bark probably was diagnostic for a 'natural' group, which they defined by excluding certain taxa from Blakely's (1955) E. sect. 'Macrantherae Normales'. Their group corresponded closely with that which Pryor \& Johnson (1971) later circumscribed informally as sect. Maidenaria. Carr \& Carr reported that only a handful of species lacked bark glands while otherwise appearing to belong in the group. Thorough examination of the bark of E. recurva from all parts of the stems, as well as the lignotuber, has failed to reveal any oil glands. Possibly, $E$. recurva develops glands only in the older plant, like E. globulus Labill. subsp. bicostata (Maiden et al.) Kirkpatrick, E. rubida Deane \& Maiden and E. viminalis Labill. (Carr \& Carr 1969: 477); however, the plants at Braidwood appeared to be quite mature. Despite its apparent lack of bark glands, $E$. recurva is so similar to certain species in sect. Maidenaria that there can be little doubt that it belongs there.

Within sect. Maidenaria, the affinities of $E$. recurva are less clear. Table 1 compares $E$. recurva with some other taxa from this section. Several characters shown by $E$. recurva are otherwise virtually unknown in the section: a scarious, dehiscent outer operculum; markedly recurved leaves and obovate juvenile to early intermediate leaves (Figs 1-2). Such characters are scarcely informative about affinity, since they serve mainly to diagnose the species itself.

More or less scarious outer opercula occur in three other members of sect. Maidenaria: E. nitens (Deane \& Maiden) Maiden, E. quadrangulata Deane \& 
Table 1. Comparison of Eucalyptus recurva with some other taxa in sect. Maidenaria

\begin{tabular}{|c|c|c|c|c|}
\hline \multirow[t]{2}{*}{ Characters } & \multicolumn{4}{|c|}{ States in taxa } \\
\hline & E. recurva & E. vernicosa & E. johnstonii & E. parvifolia \\
\hline Plant height (m) & $1.3-1.7$ & $0.3-5$ & $20-50$ & $5-10$ \\
\hline Bark glands & - & + & + & + \\
\hline Leaves recurved & all stages & $\begin{array}{l}\text { occasional in } \\
\text { seedlings }\end{array}$ & - & $\begin{array}{l}\text { intermediate } \\
\text { (slightly) }\end{array}$ \\
\hline $\begin{array}{l}\text { Leaf type in adult } \\
\text { plant }\end{array}$ & intermediate & $\begin{array}{l}\text { intermediate to } \\
\text { adult }\end{array}$ & adult & $\begin{array}{l}\text { intermediate to } \\
\text { adult }\end{array}$ \\
\hline $\begin{array}{l}\text { Internode length in } \\
\text { adult plant }(\mathrm{mm})\end{array}$ & $6-12$ & $2-15$ & $10-25$ & $3-20$ \\
\hline $\begin{array}{l}\text { Seedling stems } \\
\text { quadrangular }\end{array}$ & + & + & + & - \\
\hline $\begin{array}{l}\text { Seedling stems } \\
\text { winged }\end{array}$ & + & + & + & - \\
\hline $\begin{array}{l}\text { Seedling stems } \\
\text { glandular }\end{array}$ & + & + & + & - \\
\hline $\begin{array}{l}\text { Seedling leaf } \\
\text { length, 6th node } \\
(\mathrm{mm})\end{array}$ & 18 & $22^{1}$ & $36^{1}$ & $19^{1}$ \\
\hline Juvenile leaf shape & $\begin{array}{l}\text { obovate to } \\
\text { narrow-obovate }\end{array}$ & ovate to orbicular & ovate to orbicular & ovate to orbicular \\
\hline $\begin{array}{l}\text { Intermediate leaf } \\
\text { length }(\mathrm{mm})\end{array}$ & $6-13$ & $10-40$ & $12-50$ & $10-40$ \\
\hline $\begin{array}{l}\text { Maximum adult leaf } \\
\text { length }(\mathrm{mm})\end{array}$ & inapplicable & 50 & 150 & 70 \\
\hline $\begin{array}{l}\text { Number of buds in } \\
\text { uniflorescence }\end{array}$ & 3 & $1-3$ & 3 & 7 \\
\hline $\begin{array}{l}\text { Outer operculum } \\
\text { type }\end{array}$ & $\begin{array}{l}\text { scarious, } \\
\text { persistent, } \\
\text { dehiscing } \\
\text { irregularly }\end{array}$ & $\begin{array}{l}\text { coriaceous, } \\
\text { caducous, intact }\end{array}$ & $\begin{array}{l}\text { coriaceous, } \\
\text { caducous, intact }\end{array}$ & $\begin{array}{l}\text { coriaceous, } \\
\text { caducous, intact }\end{array}$ \\
\hline
\end{tabular}

${ }^{1}$ Population means, $\mathrm{n}=6$ (unpublished data provided by $\mathrm{J}$. Chappill).

Maiden and E. benthamii Maiden \& Cambage var. benthamii. However, in the latter two taxa, the outer operculum differs from that of $E$. recurva in subtleties of texture and colour, in ultimately falling off, and in not always dehiscing. The outer operculum of $E$. nitens is very similar in all respects to that of E. recurva, but marked differences in many other characters suggest that these species are not closely related.

Neotenous retention of intermediate leaves in the mature plant, an obvious feature of $E$. recurva (Figs $1,2 \mathrm{E}$ ), occurs sporadically through sect. Maidenaria, and has probably evolved in parallel more than once. The same can be said of 3 -flowered unit inflorescences. Bud and fruit shapes in E. recurva (Fig. 2D-E) are broadly similar to those in a number of species in sect. Maidenaria, and thus are not informative about affinity.

By its diminutive habit, small leaves, short internodes and retarded development of adult leaves, E. vernicosa Hook. f. resembles E. recurva (Table 1). However, all these traits may be correlated with extreme environmental 
conditions. It has been suggested that $E$. vernicosa is only one end of an altitudinal cline which grades through $E$. subcrenulata Maiden \& Blakely to $E$. johnstonii Maiden (Potts \& Jackson 1986). Individuals of E. johnstonii are very tall forest trees with longer internodes and normally developed adult leaves (Table 1). Therefore, it seems unwise to postulate that diminutive habit, short internodes and delayed development of adult leaves are evolutionary novelties defining a monophyletic group composed of E. recurva and E. vernicosa.

There are a number of similarities between $E$. recurva and E. parvifolia. Pryor \& Johnson (1971) placed the latter in sect. Maidenaria, between $E$. sturgissiana L. Johnson \& Blaxell and E. crenulata Blakely \& de Beuzeville, although Johnson (pers. comm.) no longer agrees with that particular placement. Among the characters held in common by $E$. recurva and $E$. parvifolia are small leaf size and retention of intermediate leaves in the mature plant (Table 1). Although E. parvifolia does eventually develop scattered, petiolate, lanceolate adult leaves, the petioles are very short, not exceeding about $5 \mathrm{~mm}$. Moreover, these species have very similar intermediate leaves, except that those of $E$. parvifolia do not taper to the base nor are markedly recurved. No other member of sect. Maidenaria has leaves as small, particularly in length, except $E$. vernicosa (Table 1). Lower-altitude forms of the $E$. vernicosa-E. johnstonii cline have much larger intermediate and adult leaves (Table 1) because, as has been stated above, leaf-size in this complex is environmentally correlated. Environment is less likely to be affecting leaf size in $E$. recurva or E. parvifolia. Both grow at similar altitudes $(600$ and $1000 \mathrm{~m}$ respectively) on similar topography and soils on the eastern side of the Southern Tablelands of New South Wales, a more benign habitat than that of $E$. vernicosa. The habitat of $E$. vernicosa is extreme: very exposed rocky ridges in the Tasmanian alpine zone.

Seedlings of $E$. recurva and the $E$. vernicosa complex share some distinctive characters: stems which are quadrangular, narrowly winged and abundantly glandular (Table 1). All these characters are also seen in E. imlayensis Crisp \& Brooker (1980), a close relative of the E. vernicosa complex. Quadrangular, winged seedling stems are not uncommon in sect. Maidenaria, but they are certainly not found in $E$. parvifolia. Nor does $E$. parvifolia have conspicuous glands along the stems of its seedlings. Although it is stated above that markedly recurved leaves are virtually unique in $E$. recurva, seedlings of $E$. vernicosa occasionally develop slightly recurved leaves (J. Chappill, pers. comm.). In E. parvifolia also, the intermediate leaves are slightly recurved. However, neither species shows the consistency (through all ontogenetic stages) or degree of recurvature seen in E. recurva. Therefore it is unclear whether these vague similarities represent genuine homologies.

In conclusion, it appears that $E$. recurva, while definitely belonging in the informal Eucalytus sect. Maidenaria, is taxonomically well distinguished from any known species, but perhaps is closest to the $E$. vernicosa complex.

\section{Acknowledgements}

I wish to thank Robin Jean and Greg Baker for all their assistance. Jenny Chappill, Alan Gray and Lawrie Johnson kindly made comments upon the manuscript. Thanks to Gavin Moran for carrying out the electrophoretic analysis. The production of this manuscript was made possible by a grant from the Nell and Hermon Slade Trust. 


\section{References}

Blakely, W.F. (1955) 'A Key to the Eucalypts'. Edn 2 (Forestry \& Timber Bureau: Canberra).

Boland, D.J., Brooker, M.I.H., Chippendale, G.M., Hall, N., Hyland, B.P.M., Johnston, R.D., Kleinig, D.A., \& Turner, J.D. (1984). 'Forest Trees of Australia'. Edn 4 (Nelson/CSIRO: Canberra).

Carr, S.G.M., \& Carr, D.J. (1969) Oil glands and ducts in Eucalytus L'Hérit. I. The phloem and the pith. Austral. J. Bot. 17: 471-513.

Chippendale, G.M. (1973) 'Eucalypts of the Western Australian Goldfields' (Austral. Govt Publ. Serv.: Canberra).

Crisp, M.D., \& Brooker, M.I.H. (1980) Eucalyptus imlayensis, a new species from a mountain of south coastal New South Wales. Telopea 2: 41-47.

Ellyard, R.K. (1987) Conservation of Australia's endangered plants - a role for the Australian National Botanic Gardens. Pp. 73-79 in J.A. Armstrong (ed.), 'Waratahs - Their Biology Cultivation and Conservation' (Austral. Natl Bot. Gard. Occas. Publ. 8: Canberra).

Fisher, W.J. (1978) A basis for the selection and management of scientific areas in Queensland state forests. Dept Forestry Queensland Tech. Paper 14 (Dept Forestry: Queensland).

Leigh, J.H., Boden, R.W., \& Briggs, J.D. (1984) 'Extinct and Endangered Plants of Australia' (Macmillan: Melbourne).

Potts, B.M., \& Jackson, W.D. (1986) Evolutionary processes in the Tasmanian high altitude eucalypts. Pp. 511-527 in B.A. Barlow (ed.), 'Flora and Fauna of Alpine Australia, Ages and Origins' (CSIRO: Melbourne).

Pryor, L.D., \& Johnson, L.A.S. (1971) 'A Classification of the Eucalypts' (Austral. Natl. Univ.: Canberra).

Manuscript received 22 April 1987

Manuscript accepted 19 June 1987 